\title{
The Kiai's Efforts In Developing Multicultural Education In Pesantren Langitan Widang Tuban
}

\author{
Sudarto Murtaufiq \\ Faculty of Islamic Studies Islamic University of Lamongan \\ E-mail: murtaufiq@unisla.ac.id \\ Victor Imaduddin Ahmad \\ Faculty of Islamic Studies Islamic University of Lamongan \\ E-mail: victorimaduddin109@unisla.ac.id
}

\begin{abstract}
The presence of Muslim clerics (kiai) in Langitan Islamic boarding school (pesantren) Widang Tuban is very unique to be taken into account, especially from their duties and function. They have provided direction or input in curriculum preparation, created an evaluation system, formulated institutional rules and organized the life of the entire pesantren community as well as their role as community leaders. This study focuses more on the efforts of kiai in developing multicultural Islamic education for considering that this pesantren has undergone changes and renewal but is not inseparable from traditional roots which are proven to be laden with multicultural educational values. In reality, this kind of pesantren has produced many students and graduates who have inclusive, moderate and tolerant viewpoints. This study uses a descriptive qualitative approach. Data collection is caccried out through such methods as observation, interviewes and documents. The results of this study showed that the efforts of the kiai in developing multicultural Islamic education in Pesantren LangitanWidang Tuban are: firstly, building a multicultural Islamic education epistemology based on the al-Qur'an and Hadith. Secondly, sharpening the values of multiculturalism in curriculum. Thirdly, fostering students' spiritual growth (spiritualization of students).
\end{abstract}

Keyword: Pesantren community, Islamic education, multicultural values

\section{Introduction}

In cultivating the multicultural values in Islamic boarding school (pesantren), clerics (kiai) have such roles as leaders, teachers and guide for students as well as husbands and fathers in their own families who also live in the pesantren. The roles are so complex for requiring them to be able to position themselves in various situations. So addressing the need of having kiai who have the ability, dedication and high commitment to carry out these roles is a must. The position of kiai as the leaders of pesantren is also required to uphold the noble values that become their reference in behaving, acting and developing pesantren. In fact, the noble values believed by kiai or Muslims are a strength that is considerably a gift from Allah SWT.

The existence of kiai as leaders in Pesantren LangitanWidang Tuban is very unique to be studied because from the point of view of their duties and functions, the kiai have not only provided direction in dealing with curriculum preparation, created an evaluation system and 
formulated institutional rules, but rather organized the life of pesantren and surrounding communities.

This is as explained by Muhammad Hanif Fahruddin, alumnus of Pesantren Langitan Tuban, as follows:

The so-called Dewan Masayikh (pesantren leaders council) plays a major role in providing direction and guidance on the curriculum content taught in Pesantren Langitan. All rules or decisions and whatever they are called must be approved beforehand from the kiai in this pesantren. In addition to being involved in curriculum development in pesantren, the kiai also often provide direction, guidance, as well as role models to the surrounding community or alumni that almost every day take the time to visit the kiai's houses (dalem). In their leadership role for the life of the wider community, the kiai have also delivered religious sermons in various places in the surrounding area, and this is usually done routinely at mosques, where the kiai's religious gathering is held. ${ }^{1}$

Therefore, the research on kiai as spiritual leaders in developing multicultural education in this pesantren is very important and interesting, considering that this pesantren has more or less undergone changes and renewal but is not separated from traditional roots which are proven to be laden with multicultural educational values. In reality, this kind of pesantren has produced many students and graduates who have an inclusive, moderate and tolerant viewpoints, and who love their country.Thus, this study aims to know the efforts of kiai in developing multicultural education in Pesantren LangitanWidang Tuban.

The research on the efforts of kiai in developing multicultural Islamic education in Pesantren Langitan Tuban is a qualitative one. According to Bogdan and Taylor cited by Lexy J. Moloeng, qualitative method is "a research procedure that obtains descriptive data in written or spoken form from the people and their behavior which is being observed. ${ }^{2}$

While the paradigm used in this study is based on the philosophy of postpositivism (interpretive), by examining the natural conditions of the object (natural setting) where the researcher is the key instrument. ${ }^{3}$ Viewed from the perspective of post positivism, the objectives of qualitative research may be exploratory, theoretical and practical. So, in qualitative research it could be termed like a person taking a trip, so that he will know where to go, but of course he does not know for sure what is in that place. He will know after entering an object, by reading various written information, pictures, thinking and seeing objects and activities of people around him, conducting interviews and so on.

Thus, this research is expected to be able to find and describe the data comprehensively regarding the efforts of kiai in developing multicultural Islamic education in Pesantren Langitan Tuban.This is a case study so that the researcher attempts to investigate phenomena in the context of real life by utilizing multiple sources that exist in human life. ${ }^{4}$ Thus, this study seeks to determine the diversity and particularity of the object of study. While the result

\footnotetext{
${ }^{1}$ Ahmad Hanif Fahruddin, Interview, Tuban, 20 Oktober 2017

${ }^{2}$ Lexi Moleong, Metode Penelitian Kualitatif (Bandung: Remaja Rosdakarya, 2000), 3.

${ }^{3}$ Masykuri Bakri (ed), Metode Penelitian Kualitatif: Tinjauan Teoritis dan Praktis (Surabaya: Visipress, 2013), 53; See also Sharlene Nagy Hesse-Biber, Patricia Leavy, The Practice of Qualitative Research (Los Angeles: Sage, 2011), 88

${ }^{4}$ Robert K. Yin, Case Study Research: Design and Methods. 3rd ed (New York: Sage Publication, 2003$), 13$.
} 
of this study is to explain and describe the efforts of kiai in developing multicultural Islamic education in Pesantren LangitanWidang Tuban.

\section{Pesantren Langitan: Profile, Teaching Methods and Educational Infrastructure}

The results of research conducted in Pesantren LangitanWidang Tuban include a brief description of the Pesantren Langitan's profile and the efforts of kiai in developing multicultural Islamic education in Pesantren LangitanWidang Tuban.Nearly two centuries Pesantren Langitan has greatly contributed to the empowerment of human resources and the intellectual life of the Indonesian nation. Gold ink streaks have been engraved and are an irreversible historical fact.Seeing the magnitude of the role of Pesantren Langitan in dealing with religion, society and the nation, many are sympathetic and give a positive response to the existence of the long-standing pesantren.

Pesantren Langitan is one of the oldest Islamic educational institutions in Indonesia and was established before the Indonesia's independence, exactly in 1852 in Mandungan ,Widang, Tuban, East Java. Pesantren Langitan is located north of the so-called Bengawan Solo and is located on a land area of approximately 7 hectares and at an altitude of approximately 7 meters above sea level.

The pesantren's location is about 400 meters south of Widang sub-district or approximately $30 \mathrm{~km}$ south of Tuban City which is also adjacent to Babat village, Babat subdistrict, Lamongan and only separated by a bridge that crosses Bengawan Solo.

\section{Education and Teaching}

The objectives of education and teaching in Pesantren Langitan are inseparable from three basic points, namely teaching students to be good human beings who have broad understanding of religious knowledge in addition to willing to put their knowledge into practice; willing to sacrifice and strive in upholding Islamic laws to foster students to become human beings who have a good personality, are pious and obedient to Allah and are willing to carry out the religious teachings; fostering students who are proficient in religious issues in addition to solving various problems emerging in the midst of society.

Pesantren Langitan during a long period of time has implemented several methods of education and teaching in the so-called madrasah and ma'hadiyah system.

\section{a. Classical System (Madrasiyah)}

This classical education system is a formalistic teaching model. Educational orientation and teaching are formulated regularly and procedurally including curriculum, levels, and educational activities. There have been three educational institutions using this classical system for both male and female Islamic boarding schools, namely Al falakiyah, Al mujibiyah, and Al-Roudhoh.

In Pesantren Langitan, thera are extracurricular activities include problems deliberation or so-called munadharah (discussion). The deliberative activity takes place every night excluding Wednesday night and Friday night. This is intended as a means for students to study and deepen topics or problems contained in each so-called Kitab Kuning. This is also expected to produce potential generations who have critical thoughts and broad insights and are skilled in absorbing and exploring material as well as disseminating it to the wider community. 
Muhafadzoh or memorization. This method is a system that is considerably very synonymous with traditional education, including pesantren. This is also binding on every student and is held every Tuesday night. The standards of the books that are used as the object of memorizing are in accordance with their respective levels are Aqidatul Awam, Hidayatussibyan, TashrifIstilahi and Lughawi, QowaidulI'lal, Matan Al Jurumiyah, TuhfatulAthfal, Arbain Nawawi, Imriti, maksud Ijazul Farid, Alfiah Ibnu Malik, Jawahirulmaknun, sulamulmunawaroq, and Qowaidulfiqhiyah.

\section{b. Non-Classical System (Ma'hadiyah)}

The non-classical education in Pesantren Langitan uses the so-called weton or bandongan and sorogan methods. The weton or bandongan method is a recitation model in which a kyai or ustadz reads and describes the contents of the yellow book while students listen and give meaning.

The sorogan method is the opposite, namely students read while the kiai or ustadz listens while providing corrections, comments or guidance as needed. Both of these methods have the same important value and character of emphasis on understanding a subject matter. Both of them complement each other.

In practice, this non-classical system or ma'hadiyah is divided into two groups; first, general non-classical education program which is held every Monday, Tuesday and Friday. Its time varies according to activities at the madrasa. This education is directled taught by the so-called Dewan Masayikh and senior santri. Second, special education program that is prioritized for post-senior high students and other santri who are considered to have mastered basic knowledge such as NahwuShorof, religious creeds, sharia. This program is more popularly called musyawirin and is directly taught by Dewan Masayikh. Its time is every day except Tuesday and Friday. The material taught is Islamic jurisprudence (fiqh) such as Fathul Wahab, FathulMu'in, Muhadzab and Hadith.

\section{c. TahfidzQurán}

In addition to the classical and non-classical education systems, Pesantren Langitan has also provided educational programs for tahfidzul Qur'an or memorizing the Qur'an. Students who wish to memorize the Qur'an are provided with special dormitories.

\section{Facilities and infrastructure}

The demand for an attainment of knowledge is closely related to the availability of representative facilities and infrastructure. In this case, the concrete efforts made by Pesantren Langitan are structuring, preserving and developing in the field of facilities and infrastructure. The facilities provided by Pesantren Langitan include living quarters, dormitories, places of worship, teaching and learning buildings, canteens, shopping centers, nursing rooms (poskestren), library buildings, language and computer laboratories, science laboratories, telecommunication stalls, training and skills building, sports field, savings for Santri

Darul Ghuroba is one of the Pesantren Langitan dormitories and has its own specialties. Darul Ghuroba' built and founded by KH. Ubaidillah Faqih, is localed about 300 meters from Pesantren Langitancenter location. The santri who live there are those who are commonly from poor families and are free from any fees, such as daily meals, 
school fees, books and others. In its administrative management, Darul Ghuroba 'has its own authority to regulate itself without interference from the so-called Pondok Induk. This means that Darul Ghuroba' is like an autonomous body under the auspices of Pesantren Langitan.

\section{Biographies of Pesantren Leaders}

The existence of Pesantren Langitan was originally only a small mosque. It has now rapidly developed into a quality and popular educational institution among the wider community, both nationally and internationally. This glorious achievement cannot be separated from the services of its leaders who with sincerity and commitment have devoted all their potential to the progress and development of the pesantren.

Hadrat KH. Muhammad Nur is the first founder of Pesantren Langitan. Through a small mosque, his persistence and sincerity to provide religious knowledge for his family and neighbors during the colonial period marked the important roles played by Pesantren Langitan that has till now continued to exist in producing cadres of religious warriors and pious people.KH. Muhammad Nur is a descendant of a cleric from Tuyuhan Village, Rembang, Central Java. He is also a descendant of Mbah Abdurrahman, Pangeran Sambo. He cared for the pesantren for approximately 18 years (1852-1870 AD).

After the death of KH. Muhammad Nur, the leadership of Pesantren Langitan was continued by KH. Ahmad Sholeh, the second son of the nine sons and daughters of KH. Muhammad Nur.

In addition to studying the Qur'an to his father, KH. Ahmad Sholeh also studied the Qur'an to KH. Abdul Qodir in Sidoresmo Surabaya and also had time to do religious studies to several major Muslim scholars of the Masjidil Haram, including Sheikh Ahmad ZainiDahlan when he performed the pilgrimage to Makkah in $1289 \mathrm{H}$.

During the KH Ahmad Sholeh's nurture, Pesantren Langitan has developed quite rapidly in terms of both quantity and quality. This is evidenced by the increasing number of students, including in terms of its adequate and representative facilities and infrastructure.

Such prominent Muslim scholars as KH. Muhammad Kholil (SyaikhonaKholil) Bangkalan Madura, KH. Hasyim Asy'ari (the founder of Nahdlatul Ulama), KH. Wahab Hasbullah-Jombang, KH. Syamsul Arifin (the father of KH. As'adSyamsul Arifin), KH. Shidiq (the father of former Supreme Leader (Rais Aam) of Nahdlatul Ulama, KH. Ahmad Shiddiq), KH. Khozin (who later continued the chain of KH. Ahmad Sholeh's leadership), KH. Hasyim-PadanganBojonegoro, KH. Umar Dahlan-Sarang Rembang and others were a number of students who had attended Pesantren Langitan during the KH. Ahmad Sholeh's leadership. A proud historical fact, where an educational institution with all its limited facilities was able to produce the great scholars of the archipelago.

KH. Ahmad Sholeh developed this pesantren for approximately 32 years (1870-1902 $\mathrm{AD})$. he died in $1320 \mathrm{H}$, coinciding with $1902 \mathrm{AD}$, and was buried in a public cemetery in Mandungan Village, Widang, Tuban, approximately 400 meters north of the pesantren.

The third period of Pesantren Langitan was led by the KH Ahmad Sholeh's son-in-law, namely KH. Muhammad Khozin, the son of KH. Shihabuddin-Rengel Tuban.In addition to studying at Pesantren Langitan, he also studied at Pesantren Kademangan under the leadership of KH. Mohammad KholilBangkalan, for two years. In 1894 AD, he was married 
to the KH Ahmad Sholeh's daughter, Ning Shofiyah and since then he began to actively teach until he accepted the noble task of leading and caring for the pesantren after the death of his father-in-law in $1320 \mathrm{H} / 1902 \mathrm{AD}$.

As time passed, several years later, exactly in $1904 \mathrm{AD}$, he had the opportunity to make the pilgrimage to Makkah. This golden opportunity was used to study religious subjects to Sheikh Makhfudz at-Termasi and several other prominent Muslim scholars in Mekkah.

KH. Muhammad Khozin developed Pesantren Langitan for approximately 19 years (1902-1921 AD). He died in $1340 \mathrm{H} / 1921 \mathrm{AD}$ and was buried in a public cemetery in Mandungan Village, Widang, Tuban.

The chain of the pesantren's leadership was still ongoing. In its fourth period, Pesantren Langitan was under the leadership of the KH Muhammad Khozin's son-in-law, Hadrat KH. Abdul Hadi Zahid. He was born in Kauman Village, Kedungpring Subdistrict, Lamongan, on the 17th of Rabi'ulAwwal $1309 \mathrm{H}$.

Since he was eleven years old he had started studying at Pesantren Langitan until the age of nineteen. KH. Muhammad Khozin then adviced him to continue his studies at Pesantren KademanganBangkalan Madura under the leadership of KH. Muhammad Kholil for three years. When KH. Abdul Hadi was 23 years old, he studied at Pondok Pesantren Jamsaren Solo under the leadership of KH. Idris. After that, he returned to study at Pesantren Langitan until he was 25 years old. He was married to Ning Juwairiyah, the daughter of $\mathrm{KH}$. Muhammad Khozin.

At a relatively young age, 30 years old, he received a heavy duty as the leaders of Pesantren Langitan. Even, under his leadership, Pesantren Langitan at that time experienced significant developments. It is proven that since this period (1949 AD) a classical teaching system began to be developed by establishing the so-called Madrasah Ibtida'iyah and Madrasah Mu'allimin and extra-curricular activities such as BahtsulMasa'illilWaqi'iyyah, Jam'iyatulMuballighin, Jam'iyyatulQurro' walHuffadz and others. In addition, routine activities in the form of recitation of books, both the sorogan and the weton systems, were still preserved and developed, especially congregational prayer.

After the death of KH. Abdul Hadi Zahid, the the leadership of Pesantren Langitan was then mandated to his younger brother; KH. Ahmad Marzuqi Zahid and also his nephew; KH. Abdullah Faqih.

KH. Ahmad Marzuqi Zahid was born in Kauman Village, Kedungpring, Lamongan on Thursday Pon, 22 Jumadal Ula 1327 H (June 10, 1909 AD). He was the 9th son of 11 sons and daughters of KH. Zahid and Nyai 'Alimah. They are:KH. Abdul Hadi, Mutmainnah,Tashrifah, Zainab, KH. Muhammad Rofii (father of KH. Abdullah Faqih), Musfi'ah, 'Aisyah

Musta'inah, KH. Ahmad Marzuqi, Hindun, Maryam .

When he was 10 years old, KH Marzuki Zahid began to continue his studies and deepen his religious knowledge at Pesantren Langitan under the leadership of KH. Abdul Hadi Zahid who is his own older brother. For decades he deepened and improved his intellectual capabilities in all religious disciplines diligently and patiently. In addition to studying at Pesantren Tebuireng under the guidance of a great Muslim scholar, Hadrat KH. Hasyim Asy'ari, who was also an alumnus of Pesantren Langitan during the KH. Muhammad Sholeh's period, he also studied calligraphy to KH. Basuni, Blitar, East Java. 
Because of his outstanding capabilities and credibility in the field of religious knowledge, he received a mandate from KH. Abdul Hadi Zahid to become a teacher at Pesantren Langitan. In addition to having extensive mastery of religious knowledge, he also had a lot of knowledge about the basics of organizational management so that in 1944 AD he was trusted to be the head of the pesantren (now popularly known as Rais Aam). He carried out these noble tasks with full diligence, patience and consistency, finally when he was 36 years old he was married to Ning Halimah, the daughter of KH. Zaini (PambonBrondongLamongan) who is also the son the KH Muhammad Khozin's son-in-law.

KH. Ahmad Marzuqi Zahid began to concentrate more on the internal affairs of the pesantren when he and KH. Abdullah Faqih received the mandate to continue the chain of leadership of Pesantren Langitan after the death of KH. Abdul Hadi Zahid on April 5, 1971 M.

The aspirations and hopes of the pesantren's predecessors could brilliantly and wisely be carried out by both KH. Ahmad Marzuqi Zahid and KH. Abdullah Faqih. The synergic collaboration between the two Muslim scholars in leading the leadership wheel of Pesantren Langitan could yield tremendous and significant results.

The success of the father of nine sons in carrying out all his activities, especially in caring for the pesantren cannot be separated from the services of his wife, NyaiHalimah, who with great patience and sincerity devoted all her sacrifices to accompanying and devoting herself to helping her husband's duty in both joy and sorrow. He and NyaiHalimah were blessed with nine sons and daughters who would later become the successors of their father and mother's struggle in upholding the teachings of Islam. His nine sons and daughters are: 1) Ning Khalifah (died at a young age); 2) Ning Muflihah (wife of KH. DimyatiRomli, Pesantren Darul Ulum Jombang); 3) KH. Abdullah Munif (married to $\mathrm{NyaiHj.}$ QurrotulIshaqiyyah, Surabaya); 4)NyaiHj. Faizah (wife of KH. Sholeh Badawi, Langitan); 5) KH. Muhammad Ali (married to NyaiHj. Aisyah, Surabaya); 6) Ning Mahampang (wife of KH. Basthomi, Nganjuk); 7) Ning NihayatusSa'adah (wife of Agus A'la Bashir, Madura); 8) Ning Shofiyah (wife of Agus H. Abdul Rozaq, Sumedang, West Java); 9) Ning Masrurah (wife of Ust. Miftahul Munir, Manyar Gresik)

After for about forty-seven years devoting all her potential in accompanying and helping to ease the burden on her husband in upholding the teachings of Islam, NyaiHalimah passed away on June 6, 1992 AD. Two years after the NyaiHalimah's death, exactly on April 7, 1994 M. KH. Ahmad Marzuqi Zahid married NyaiSholihah from Manyar Village, Sekaran Subdistrict, Lamongan, who accompanied him until the end of his life.

On Saturday, 21 Rabi'ulAwwal 1421 H (June 24, 2000 M) KH. Ahmad Marzuqi Zahid died at the age of 91 years, after leading the Pesantren Langitan for approximately 29 years (1971-2000 AD).After the death of KH. Ahmad Marzuqi Zahid, the leadership of Pesantren Langitan was continued by KH. Abdullah Faqih, a low profile figure.

KH. Abdullah Faqih is three brothers from the Kyai Rofi'i Zahid and NyaiKhodijah's marriage. His brothers are Khozin and Hamim. Since childhood, KH Abdullah Faqih and his two younger brothers had been cared for by KH. Abdul Hadi Zahid (fourth generation of the Pesantren Langitan).

KH. Abdullah Faqih was born on May 2, 1932 AD. In addition to studying directly to his father (KH. Abdul Hadi Zahid), he also had time to study in several pesantren. $\mathrm{KH}$ 
Abdullah Faqih is well known for his religious knowledge, wisdom and piety. KH. Abdullah Faqih in his youth only studied in some pesantren not more than 4 years. On one occasion he once said, in Lasem studing in pesantren for two and a half years, in Senori for six months and one month in another pesantren.

KH. Abdullah Faqih, after approximately 41 years leading the Pesantren Langitan passed away on Wednesday, February 29, 2012. A sea of tears accompanied his death, even the clouds also overshadowed his body to his final resting place.

Pesantren Langitan has still continued the struggle of its previous leaders, the sons of the late KH. Abdullah Faqih have and will continue the chain of leadership of the pesantren. Such prominent figures as KH. Abdullah MunifMarzuqi, KH. Ubaidillah Faqih, KH. Muhammad Ali Marzuqi, KH. Muhammad Faqih, KH. Abdullah Habib, KH. Abdurrahman Faqih have committed to maintaining the values instilled by their predecessors by continuing to develop and bring Pesantren Langitan to a better future.

The biography of the late KH. Abdullah Faqih could be read the book 'The Portrait of an Example of Syaikhina KH. Abdullah Faqih'.

In addition to being led and managed by the so-called Dewan Masyayikh (the council of pesantren leaders), Pesantren Langitan has also been assisted by several pesantren family members, the so-called A'wan Council and the Advisory Council.

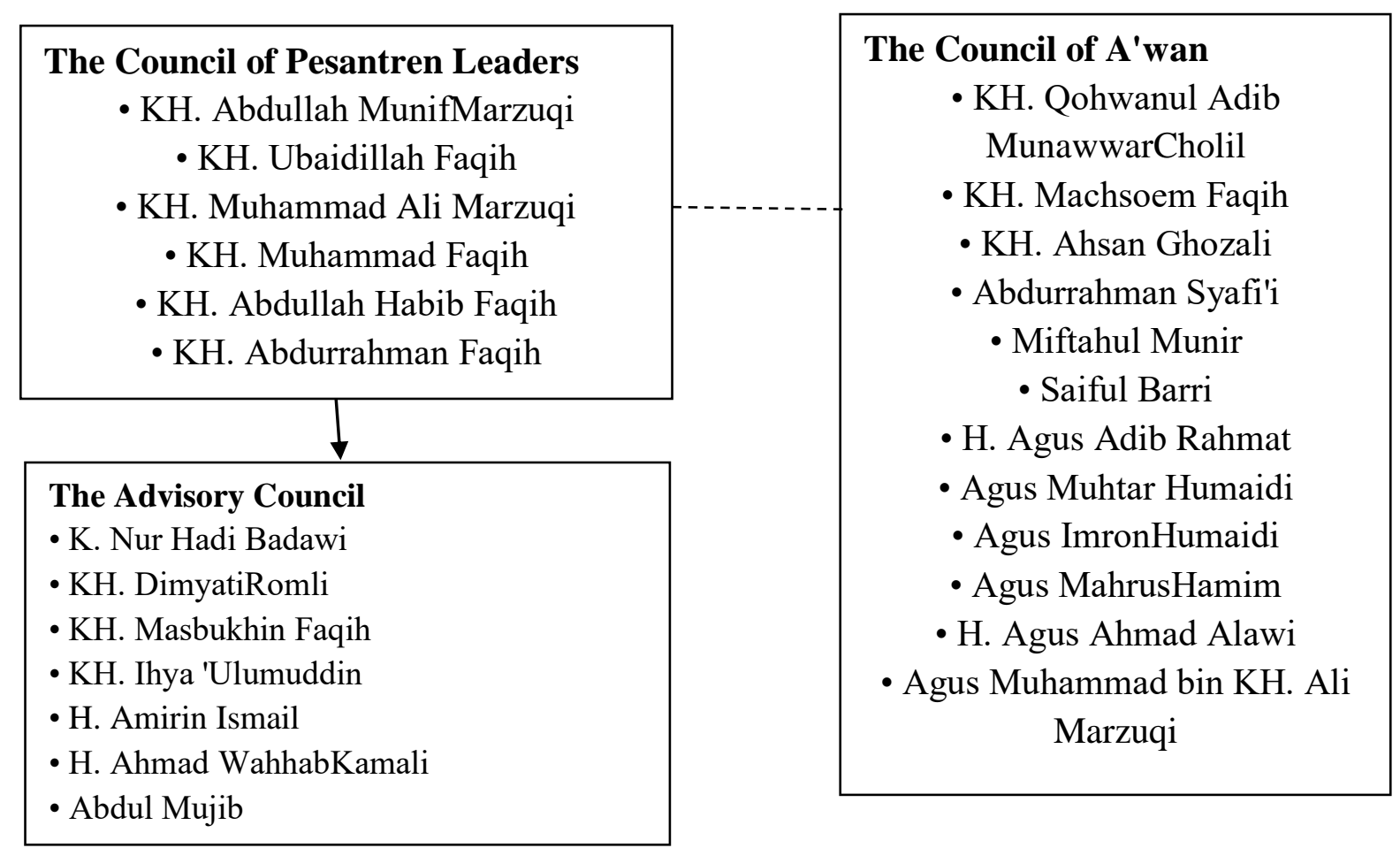

Chart 1.

The board structure of the Langitan Islamic Boarding School 


\section{The Kiai's efforts in Developing Multicultural Islamic Education in Pesantren LangitanWidang Tuban}

\section{Building a multicultural Islamic education epistemology based on the Qur'an and Hadith}

Multicultural Islamic education has a very strategic role in the process of cultivating and transferring multicultural values such as democracy, equality, justice, humanity, togetherness, peace, an attitude of acknowledging, accepting and respecting diversity. Within this framework, the multicultural Islamic education is in one breath with the national education which lays down one of its principles that education is carried out in a democratic and just manner and is not discriminatory by upholding human rights, religious values, cultural values, and national diversity. ${ }^{5}$

It is understood that Pesantren Langitan has a long and unique history. This uniqueness could be seen historically that this pesantren is one of the old pesantren in Indonesia that has existed to this day. The presence of Pesantren Langitan is none other than to spread Islamic teachings that bring grace to all nature and respect diversity as a reality and the concept of rahmatanlil alamin becomes the cultural foundation of its teachings.

According to KH Abdurrahman Faqih, Pesantren Langitan has both the role and the spirit of struggle as an educational institution and part of developing Islamic teachings that are friendly and full of multicultural values. These multicultural values are actually reflected in the theQurán and Hadith.

"One of the main missions of this pesantren is to organize an Islamic education process that is quality oriented, and based on spiritual, intellectual and moral attitudes in order to give birth to cadres of Muslim scholars (ulama) who become the blessings for the universe (rahmatanlil alamin)."6

Thus, it is clear that Pesantren Langitan is committed to producing cadres of ulama who have broad religious understanding and practice their knowledge in a pluralistic society. In a broader context, the kiai encourage the students to adapt to existing situations and conditions and be able to create a harmonious life.

Along with the development of plurality in various aspects of life, the world of education, including pesantren, is facing the challenges of changing attitudes and behavior in society. So that the world of education must have steps and strategies in carrying out educational tasks to achieve predetermined goals, including the introduction of multicultural Islamic education.

In line with the KH Abdurrahman Faqih's view, KH Ubaidillah Faqih emphasized the importance of the students to harmonize in socio-cultural patterns. The success of planting multicultural education to students is part of the pesantren mission in taking their life journey to appreciate and accept any cultural diversity and build a harmonious life. ${ }^{7}$

Pesantren must share the responsibility of educating the nation's life and preparing Indonesian human resources that have knowledge and are based on solid faith and piety.

\footnotetext{
${ }^{5}$ Abdullah Aly, Studi Deskriptif Niai-nilai Multikultural dalam Pendidikan di Pondok Pesantren Modern Islam Assalaam, Jurnal Ilmiah Pesantren, Vol. 1, No. 1, (January-July 2015), 9.

${ }^{6} \mathrm{KH}$ Abdurrahman Faqih, Interview, Tuban, 16 Desember 2018.

${ }^{7}$ KH Ubaidillah Faqih, Interview, Tuban 16 Desember 2018
} 
As an Islamic struggle and preaching institution, Pesantren Langitan is responsible for spreading the teachings of Islam and actively participating in fostering the life of society, nation and state.

On this stand, the researcher finds that the values of multicultural Islamic education taught at Pesantren Langitan are based on the principles of Islamic teachings, namely the Qurán and Hadith. So that the values of multicultural Islamic education must contain at least four elements, including (1) the value of monotheism, namely the process of fulfilling the fitrah of tawhid, considering that fitrah is an essential element inherent in humans since its creation; (2) the value of worship, which is a form of servant devotion to Allah SWT; (3) the value of morality, namely good and bad norms that determine the human personality; and (4) the value of social, which includes interpersonal relationship on earth.

\section{Sharpening the Values of Multiculturalism in the Curriculum}

As a religious and community education institution, Pesantren Langitan considers the importance of a multicultural education approach in the curriculum so that students not only understand multicultural education but are also able to internalize it in everyday life.

According to KH. Muhammad Zahid, the multicultural values are found in Islamic teachings doctrinally, historically, and culturally. Thus the development of a multicultural education curriculum is imperative in an educational institution, including pesantren.

"The multicultural approach contained in the curriculum at this pesantren aims to accommodate any cultural differences of students who have different cultural and ethnic backgrounds from one another. The cultural differences brought by the students are also used as a starting point for the students to develop their own cultures. The knowledge of other people's cultures, tolerance, mutual cooperation, democracy, developing ethical behavior, and others need to be taught in educational institutions." ${ }^{8}$

The basis of the pesantren's efforts to sharpen multicultural values in the curriculum because these values have a theological foundation. According to KH Abdurrahman Faqih, the theological foundation of multicultural values could be found in the the Qur'an and Hadith.

"For example, in Surah al-Kafirun [109]: 1-6, there are multicultural values that provide a moral as well as ethical foundation that everyone is given the right to make their choice of religion. Thus, Islam does not teach its followers to force others to choose. This principle indicates that Islam highly upholds the right of others to choose a different belief and at the same time affirms that Islam does not teach the doctrine of racism." 9

Meanwhile, the curriculum development process must include three dimensions, namely curriculum as an idea, curriculum as a document, and curriculum as a process. ${ }^{10}$ These three dimensions are related to one another. First, the curriculum development as an idea. This is the first step that will determine the characteristics of the curriculum in the future: whether what will be produced is a multicultural curriculum, a monocultural curriculum, or the one that is implemented in general without paying attention to existing

\footnotetext{
${ }^{8}$ KH Muhammad Zahid, Interview, Tuban, 22 August 2018

${ }^{9}$ KH Abdurrahman Faqih, Interview, Tuban, 20 August 2018

${ }^{10}$ H.A.R. Tilaar, Paradigma Baru Pendidikan Nasional (Jakarta: Rineka Cipta, 2000), 89.
} 
cultural differences. Therefore the discussion about the dimensions of curriculum is very important.

In this regard, the curriculum that contains multicultural values taught at Pesantren Langitan is not only an instrument for students to learn subjects, but also as a means to develop the personality of students so that they have multicultural awareness and sensitivity. Technically the philosophy of the multicultural education curriculum must change from essentialism to progressivism, humanism, and social reconstruction based on the principles of Islamic teachings. Through this philosophy, society is used as a source and also an object in learning. The problems emerging in society, community needs, and community excellence could be used as subject matters. On this stand, the curriculum opens itself up to society in addition to making it a basis for developing the learning process and as a learning resource. In addition, the nature of the curriculum is more open to various developments that occur in society, including cultural changes and development.

Based on the researcher's observations at PesantrenLangitanWidang Tuban, the development of multicultural values in the curriculum is also used as a basis for the development of local and national cultures. This is based on the fact that Pesantren pesantren is widely used as a place to study for students who come from various cultural backgrounds. Cultural diversity, thus, is an invaluable resource for the development of national cultures.

Second, curriculum development as a document. This includes the development of various curriculum components such as objectives, content, learning experiences, and evaluation. Goals are the qualities that should be possessed by students based on the curriculum. The multicultural curriculum development must be open to various views and approaches to formulating goals.

Formulations based on the view of behaviorism and requiring measurable goal formulas could no longer be maintained. There are goals that are measurable and could be mastered in one or two learning experiences, but there are also goals that are only achieved in a longer learning period.

In accordance with the multicultural approach, the sources of quality contained in the curriculum are also not limited to the quality determined by scientific discipline alone. Human qualities as stated by many theorists and community members such as creativity, discipline, hard work, cooperation ability, tolerance, critical thinking, religious human beings, and so on, must be highlighted as curriculum objectives. Certain qualities that are felt to be important by certain cultural and social groups must be developed and therefore the curriculum documents must provide the possibility of developing goals in certain communities and cultural environments.

Likewise, the qualities such as the ability to participate in social life, the ability to seek and proceed information, the ability to communicate and so on must be put forward as objectives that are as important as those originating from the scientific discipline. In other words, the multicultural curriculum must be able to emphasize the function of education as equal or more important than the function of teaching.

The community as a learning resource must be used as a source of curriculum content. Therefore, certain values, morals, habits, customs / traditions, and cultural traits 
must be accommodated as curriculum content. It must be not only formal in nature, but society and cultural-guided, and open to social problems. The curriculum content must make students aware that educational institutions are not the ones that are not related to society, but are considerably social institutions that live and develop in society. ${ }^{11}$

Furthermore, the curriculum content must be able to support the curriculum objectives in developing the human quality of students. The development of process components in the curriculum as a document requires an approach that places students as subjects in learning. On this stand, students who learn and interact with learning resources (including the community) and teachers act as people who make it easy for them to learn. Therefore, in the multicultural curriculum the approach of students as subjects in learning means that the method is a teacher's tool in helping students learn.

Third, curriculum development as a process. At this stage the most determining actor is the role of teachers. They teachers are curriculum developers that at an empirical level are directly related to students. Therefore, if the developed curriculum is not in accordance with what has been determined in the curriculum as an idea and the curriculum as a document, then the curriculum as a process is no longer a continuation of both.

In a more extreme context, the curriculum as a process can be a completely different curriculum from the two. Knowledge, understanding, and attitudes, as well as the willingness of teachers related to the multicultural curriculum will greatly determine the success of implementing the curriculum as a process. There are four things that teachers must pay attention to in developing the curriculum as a process, namely: (1) the position of students as subjects in learning, (2) the way students learn is determined by their cultural background, (3) the cultural environment of the majority of the community and the students' personality are the cultural behavior entry of students, (4) the cultural environment of students is a source of learning. ${ }^{12}$

\section{Spiritualization of students}

In the perspective of Islamic education philosophy, the essence of students consists of several types: a. students are all children who are under the guidance of educators in formal and non-formal institutions. b. students in particular are those who study at certain educational institutions and receive guidance, direction, advice, learning, and various matters related to the educational process. ${ }^{13}$

Basically every child born into this world is equipped with a lot of intelligence and has the potential to become a genius human. However, this intelligence capacity is only used by humans for a few percent. As parents who love their children, of course they have a big and noble responsibility to increase their children's intelligence that has been bestowed by God, especially their spiritual intelligence. This is why, every parent needs to pay more attention to it. Spiritual intelligence is a potential that must be possessed by

\footnotetext{
${ }^{11}$ Leo Sutrisno, "Pluralisme, Pendidikan Pembelajaran dalam Tradisi Konstruktivisme" in Th. Sumartana (et.all), Pluralisme, Konflik dan Pendidikan Agama di Indonesia (Yogyakarta: Interfidei, 2001), 45.

${ }^{12}$ Nurul Asna, "Meneguhkan (kembali) Pendidikan Multikultural" in Majalah Inovasi Kurikulum edisi IV, 2003, 32.

${ }^{13}$ Hasan Basri, Filsafat Pendidikan Islam (Bandung: Pustaka Setia, 2009),88; See also Abdul Mujib, Ilmu Pendidikan Islam (Jakarta: Bumi Aksara,1991), 144.
} 
children because it has a huge influence on their life in the future. To develop this intelligence, education has a very important role.

Therefore, the efforts of the Pesantren Langitan's leaders in developing multicultural education is not only oriented to the development of the aspects of IQ and EQ, but also SQ. In an interview with KH Abdurrahman Faqih, it was stated that:

"The leadership of the kiai in this pesantren has a tremendeous influence in increasing the spiritual intelligence of students. Regarding multicultural education, the students have been taught the importance of humanizing humans regardless of their backgrounds. The ability to interact with other people, for example, is proof that they have an open awareness of living in harmony with each other. At this point, the students already have spiritual intelligence which they show with good attitudes towards others." 14

In this case, it is clear that the role played by the Langitanpesantren's leaders in sharpening the students' spirituality is very effective. Through institutionalized milticultural education messages in the pesantren environment, the students are able to absorb the spiritual dimensions of the leaders in this pesantren. Thus, they could succeed in developing multicultural education through the students's spiritual sharpening process.

Based on the researcher's observations related to the students' behavior regarding the efforts of the kiai in developing multicultural education in this pesantren, the students have been taught the importance of having multicultural sensitivity and awareness that humans were created as nationalities and tribes in order to know each other. What is the moral and spiritual obligation of the students here is that a noble human being is the one who is beneficial to other human beings and has the best character or behavior. After all, the degree of man before Allah SWT is devotion, and the form of our devotion to Allah SWT is our feeling of love and affection for our fellow human beings regardless of their origin and background.

Based on the results of the interview above, the kiai played an important role in developing multicultural education by sharpening the students' spirituality based on the principles of Islamic teachings. The principles of Islamic teachings as a blessing for the universe have inspired the life of the pesantren in seeding the values of multicultural education. The values of this multicultural education could be seen when the students play together without fighting. Their polite and smooth speech indicates that the students in this pesantren have a good personality. Even in the learning process, the students follow the lessons well, listen to the teacher's explanation and follow what the teacher instructs.

In addition to conducting interviews with several students, the researcher also made observations when the lesson was kicked off to know the situation in the classroom. Every teacher in explaining the subject matter was always associated with the life we live every day. The teacher provided an example of how to behave towards teachers, friends, parents and others. Everything the teacher said, all the students listened carefully.

As explained above, it is revealed that the teachers at Pesantren Langitan have succeeded in providing examples of improving the students' spirituality because they could become role models for all students. A good student could also be seen from the way a teacher teaches him.

${ }^{14}$ KH Abdurrahman Faqih, Interview, Tuban, 27 September 2019 


\section{Closing}

Pesantren LangitanWidang Tuban continues to make efforts in the process of cultivating and transferring the values of multicultural Islamic education. This pesantren organizes a quality-oriented Islamic education process based on spiritual, intellectual and moral attitudes in order to produce cadres of Muslim scholars (ulama) who become the blessings for the universe (rahmatanlil alamin). As for the efforts of the kiai in developing multicultural Islamic education in Pesantren LangitanWidang Tuban, are: firstly, building a multicultural Islamic education epistemology based on the the Qur'an and Hadith. Secondly, sharpening the values of multiculturalism in the curriculum. Thirdly, the spiritualization of students.

\section{References}

Aly, Abdullah. "Studi Deskriptif Niai-nilai Multikultural dalam Pendidikan di Pondok Pesantren Modern Islam Assalaam", Jurnal Ilmiah Pesantren, Vol. 1, No. 1, JanuariJuli 2015.

Asna, Nurul. "Meneguhkan (kembali) Pendidikan Multikultural" dalam Majalah Inovasi Kurikulum edisi IV, tahun 2003.

Bakri, Masykuri. (ed), Metode Penelitian Kualitatif: Tinjauan Teoritis dan Praktis. Surabaya: Visipress, 2013.

Basri, Hasan. Filsafat Pendidikan Islam. Bandung: Pustaka Setia, 2009.

Moleong, Lexi. Metode Penelitian Kualitatif. Bandung: Remaja Rosdakarya, 2000.

Mujib, Abdul. Ilmu Pendidikan Islam. Jakarta: Bumi Aksara,1991.

Recker, Jan. Scientific Research in Information Systems: A Beginner's Guide. Heidelberg: Springer, 2013.

Sutrisno, Leo. "Pluralisme, Pendidikan Pembelajaran dalam Tradisi Konstruktivisme" dalam Th. Sumartana (et.all), Pluralisme, Konflik dan Pendidikan Agama di Indonesia. Yogyakarta: Interfidei, 2001.

Tilaar, H.A.R. Paradigma Baru Pendidikan Nasional. Jakarta: Rineka Cipta, 2000.

Yin, Robert K. Case Study Research: Design and Methods. 3rd ed. New York: Sage Publication, 2003Sharlene Nagy Hesse-Biber, Patricia Leavy, The Practice of Qualitative Research. Los Angeles: Sage, 2011. 